\title{
IMPLEMENTASI ALGORITMA NAÏVE BAYES PADA PENGELOMPOKAN ASET FAKULTAS TEKNIK UNIVERSITAS MUHAMMADIYAH BENGKULU
}

\author{
${ }^{1}$ Lufti Amandha, ${ }^{2}$ Anisya Sonita
}

1,2Universitas Muhammadiyah Bengkulu, Indonesia

Iluftiamandha21@gmail.com, 2ªnisyasonita@umb.ac.id;

\begin{tabular}{l}
\hline Article Info \\
\hline Article history: \\
Received, 25/11/2020 \\
Revised, 28/11/2020 \\
Accepted, 1/12/2020 \\
\hline
\end{tabular}

\section{Kata Kunci:}

Naïve Bayes,

Aset,

Komputerisasi,

Patter Recoginition Probabilitas, Hipotesis

Keywords:

Nä̈ve Bayes,

assets,

computerized,

Patter Recoginition Probability hypothesis

\begin{abstract}
ABSTRAK
Perkembangan teknologi informasi sangat berpengaruh dalam pengelolaan data dan penyampaian informasi bagi setiap instansi sehingga mempermudah dalam pengelolaan data yang diolah secara manual menjadi berbasis komputerisasi. Sehingga dengan adanya teknologi informasi yang digunakan dalam bidang pengelompokan atau inventaris aset barang-barang, setiap pencatatan dapat didokumentasikan sebagai barang bukti. Pada Fakultas Teknik Universitas Muhammadiyah Bengkulu juga menerapkan sistem sebagai pengelolaan data asset seperti computer, infokus dan printer, sebagai data inventaris. Dengan menerapkan algoritma Nä̈ve Bayes diharapkan dapat mengetahui atau memprediksi data inventaris atau data aset yang ada. Teorema keputusan bayes itu sendiri adalah pendekatan statistik yang fundamental dalam pengenalan pola (pattern recoginition). Pendekatan ini didasarkan pada kuantifikasi antara berbagai keputusan klasifikasi dengan menggunakan probabilitas dan ongkos yang ditimbulkan dalam keputusan keputusan tersebut. Ide dasar dari bayes adalah menangani masalah yang bersifat hipotesis yakni mendesain suatu klasifikasi untuk memisahkan objek. Sehingga nantinya dalam pembuatan system pengelompokan data asset ini dapat mengetahui data asset yang ada pada Fakultas Teknik Universitas Muhammadiyah Bengkulu.
\end{abstract}

\section{ABSTRACT}

The development of information technology is very influential in the management of data and delivery of information for each institution so as to facilitate the management of manually processed data into computerizedbased. So that with the information technology used in the field of grouping or asset inventory of goods, each record can be documented as evidence. At the Faculty of Engineering, University of Muhammadiyah Bengkulu also implemented a system as a management of asset data such as computer, Infokus and printer, as inventory data. Implementing the Naïve Bayes algorithm is expected to know or predict any existing inventory data or asset data. The Bayes decision theorem itself is a fundamental statistical approach in pattern recognition (pattern recoginition). This approach is based on the quantification between various classification decisions using the probability and cost incurred in the decision decision. The basic idea of Bayes is to deal with hypothesized problems that design a classification to separate objects. So later in the making system of data grouping asset is able to know the data of assets in the Faculty of Engineering University of Muhammadiyah Bengkulu. This is an open access article under the CC BY-SAlicense.

\section{PENDAHULUAN}

Perkembangan teknologi informasi telah berpengaruh dalam pengelolaan data dan penyampaian informasi bagi setiap instansi sehingga mempermudah data maupun informasi yang diolah menggunakan cara manual menjadi berbasis komputerisasi. Dengan adanya teknologi informasi yang digunakan dalam bidang pengelompokan atau inventaris aset barang-barang, setiap pencatatan sebuah aset didokumentasikan sebagai barang bukti [1]. Penerapan teknologi informasi dalam dunia inventaris ini juga dapat menghasilkan data yang berlimpah mengenai barang-barang yang ada dalam sebuah instansi. Dalam hal ini studi kasus yang diambil dalam pengelompokan data asset yaitu Fakultas Teknik Universitas Muhammadiyah Bengkulu. Dalam instansi tersebut banyak terdapat barang-barang inventaris seperti perangkat Komputer, kursi, lemari dan lain-lain yang dapat kita kelompokan dalam pencatatannya 
sehingga berguna bagi pihak fakultas untuk mempermudah mengetahui barang-barang inventaris apa saja yang mereka miliki. Dengan demikian dibutuhkanlah pengolahan data untuk mengetahui barangbarang inventaris tersebut. Pengolahan data yang dimaksud adalah klasifikasi data yang merupakan salah satu masalah mendasar dan tugas utama dalam data mining [2], dalam klasifikasi sebuah pengklasifikasi dibuat dari sekumpulan data latih dengan kelas yang telah di tentukan sebelumnya. Performa pengklasifikasi biasanya diukur dengan ketepatan data real yang ada [3]. Klasifikasi merupakan salah satu topik utama dalam data mining atau machine learning. Klasifikasi adalah suatu pengelompokan data dimana data yang digunakan tersebut mempunyai kelas label atau target. Sehingga algoritma-algoritma untuk menyelesaikan masalah klasifikasi dikategorisasikan ke dalam supervised learning atau pembelajaran yang diawasi [4].

Untuk pengelompokan data asset yang ada pada Fakultas Teknik Universitas Muhammadiyah Bengkulu maka digunakanlah suatu algoritma untuk klasifikasi atau pengelompokan yaitu algoritma Naïve Bayes. Naive Bayes merupakan sebuah pengklasifikasian probabilistik sederhana yang menghitung sekumpulan probabilitas dengan menjumlahkan frekuensi dan kombinasi nilai dari dataset yang diberikan. Algoritma mengunakan teorema Bayes dan mengasumsikan semua atribut independen atau tidak saling ketergantungan yang diberikan oleh nilai pada variabel kelas [5]. Definisi lain mengatakan Naïve Bayes merupakan pengklasifikasian dengan metode probabilitasdan statistik yang dikemukan oleh ilmuwan Inggris Thomas Bayes, yaitu memprediksi peluang di masa depan berdasarkan pengalaman di masa sebelumnya [6]. Naive Bayes merupakan algoritma klasifikasi yang sederhana dimana setiap atribut bersifat independent dan memungkinkan berkontribusi terhadap keputusan akhir [7]. Klasifikasi Bayesian didasarkan pada teorema Bayes. Studi yang membandingkan algoritma-algoritma klasifikasi telah menemukan sebuah klasifikasi Bayes yang sederhana yang dikenal sebagai klasifikasi Naïve Bayes yang dapat dibandingkan performance-nya dengan klasifikasi keputusan dan jaringan syarat tiruan [8]. Erfan dan kawan-kawan melakukan penelitian pada tahun 2018 yaitu tantang Analisis penerapan algoritma naïve bayes untuk klasifikasi prioritas pengembangan jalan di provinsi kalimantan selatan, dalam penelitiannya. Dalam penelitiannya mereka menceritakan analisis algoritma naïve bayes untuk mengklasifikasikan prioritas pengembangan jalan yang ada di provinsi Kalimantan selatan. Pertumbuhan perekonomian di Provinsi Kalimantan Selatan sangat dipengaruhi oleh lancarnya distribusi barang dan jasa. Oleh sebab itu sektor perhubungan terutama infrastruktur jalan memegang peranan sangat penting sebagai prasarana kelancaran suatu distribusi barang dan jasa [9].

Dalam pengaplikasian nya mengunakan sebuah Bahasa pemprograman PHP. Hypertext Preprocessor (PHP) adalah bahasa serverside scripting yang menyatu dengan HTML untuk membuat halaman web yang dinamis, PHP banyak dipakai untuk pemrograman situs WEB dinamis. Karena PHP merupakan serverside scripting maka sintaks dan perintah-perintah PHP akan dieksekusi di server kemudian hasilnya dikirim ke browser dalam format HTML [10]. MySQL (My Structured Query Language) adalah Suatu system basis data relation atau Relational Database management System (RDBMS) yang mampu bekerja secara cepat dan mudah digunakan. MySQL juga merupakan program pengakses database yang bersifat jaringan, sehingga dapat digunakan untuk aplikasi multi user (banyak pengguna). MySQL didistribusikan gratis dibawah lisensi GPL (General Public License). Dimana setiap program bebas menggunakan MySQL namun tidak bisa dijadikan produk turunan yang dijadikan closed source atau komersial [11].

Dengan penerapan klasifikasi atau pengelompokan data dengan algoritma Naïve Bayes diharapkan dapat mengetahui atau memprediksi data inventaris atau asset yang ada. Pada hakekatnya, Teorema keputusan bayes adalah pendekatan statistik yang fundamental dalam pengenalan pola (pattern recoginition). Pendekatan ini didasarkan pada kuantifikasi tradeoff antara berbagai keputusan klasifikasi dengan menggunakan probabilitas dan ongkos yang ditimbulkan dalam keputusan keputusan tersebut. Ide dasar dari bayes adalah menangani masalah yang bersifat hipotesis yakni mendesain suatu klasifikasi untuk memisahkan objek. [12].

Rumusan masalah yang akan dibahas adalah Bagaimana mengimplementasikan Algoritma Naïve Bayes untuk mengetahui asset yang ada pada Fakultas Teknik Universitas Muhammadiyah Bengkulu? Tujuan penelitian ini Untuk memprediksi ketepatan barang inventaris dan mengklasifikasi dan menghitung besar kesalahan klasifikasi data inventaris Fakultas Teknik Universitas Muhammadiyah Bengkulu dengan menggunakan Algoritma Naïve Bayes.

\section{METODE PENELITIAN}

\section{Metode Pengembangan Sistem}

Dalam penelitian ini model pengembangan sistem yang digunakan yaitu model Incremental. Incremental model adalah model pengembangan sistem pada rekayasa perangkat lunak 
berdasarkan perangkat lunak persyaratan yang dipecah menjadi beberapa fungsi atau bagian sehingga model pengembangannya secara bertahap.

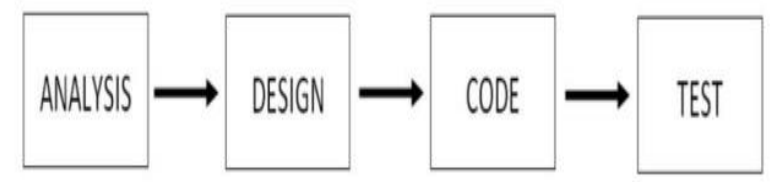

Gambar 3.1 Metode Incemental

Berdasarkan gambar 3.1 diatas, adapun penjelasan dari metode sistem incremental sistem adalah sebagai berikut :

1. Analisis proses tahapan awal yang dilakukan pada incremental model adalah penentuan kebutuhan atau analisis kebutuhan.

2. Desain tahap selanjutnya, perancangan software yang terbuka agar dapat diterapkan sistem pembangunan per-bagian pada tahapan selanjutnya.

3. Code setelah melakukan proses desain selanjutnya ada pengkodean.

4. Test merupakan tahap pengujian dalam model ini.

\section{Analisis}

Analisis data diartikan sebagai upaya mengolah data menjadi informasi, sehingga karakteristik atau sifat-sifat data tersebut dapat dengan mudah dipahami dan bermanfaat untuk menjawab masalah-masalah yang berkaitan dengan kegiatan penelitian. Dalam penelitian ini dibuat 2 analisa kebutuhan, yaitu :

1. Analisa Data

Tahapan menganalisa data dilakukan dengan :

a. Observasi

Dalam hal ini observasi dilakukan secara formal maupun informal untuk mengamati berbagai kegiatan. Dalam penelitian ini perlu dilakukan observasi untuk memperoleh informasi tentang data inventaris yang ada pada Fakultas Teknik Universitas Muhammadiyah Bengkulu.

b. Studi Pustaka

Studi Pustaka yaitu pengumpulan data yang besumber dari arsip/dokumen yang terdapat masalah-masalah mengenai Implementasi algoritma Naïve bayes dalam pengklasifikasian data dengan mencari jurnal-jurnal yang berkaitan sebagai referansi.

c. Analisa Sistem

Sistem perangkat lunak merupakan program pendukung yang diperlukan dalam menjalankan perangkat keras. Software sebagai penerjemah suatu bahasa mesin (analog)

\section{Design} yang menghasilkan informasi yang dapat dikenal oleh manusia.

Dalam tahapan design ini Menghasilkan rancangan yang memenuhi kebutuhan yang ditentukan selama tahapan analisis. Hasil akhirnya berupa spesifikasi rancangan yang sangat rinci sehingga mudah diwujudkan pada saat pemrograman.

\section{Kerangka Penelitian}

Kerangka kerja penelitian menggambarkan tahapan proses yang dilakukan dalam penelitian agar penelitian dapat berjalan dengan baik dan tujuan yang telah ditetapkan dapat tercapai. Pada penelitian ini menggunakan tahapan kerangka kerja penelitian sebagai berikut: 


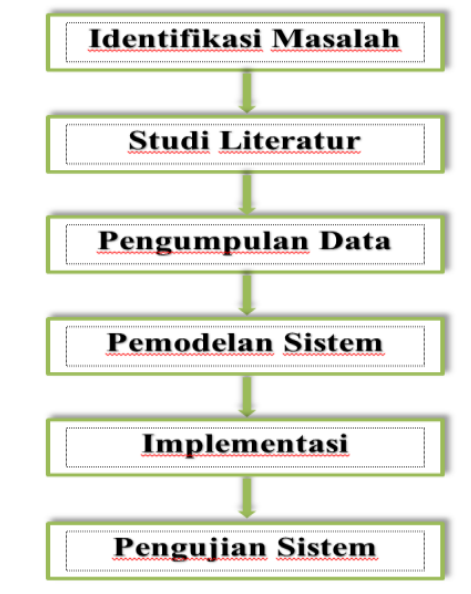

Gambar 3.2 Kerangka Penelitian

\section{Perancangan Sistem}

Perancangan adalah proses aplikasi berbagai teknik dan prinsip bagi tujuan pendefenisian suatu proses detail yang memadai untuk kemungkinan relasiasi fisiknya. Perancangan aplikasi berada pada inti teknik dari proses aplikasi yang digunakan.

\section{Diagram Konteks}

Diagram konteks merupakan diagram yang terdiri dari suatu proses dan menggambarkan ruang lingkup suatu sistem. Diagram konteks merupakan level tertinggi dari DFD yang menggambarkan seluruh input ke dalam sistem atau output dari sistem yang memberi gambaran tentang keseluruhan sistem.

Dalam diagram konteks diatas dijelaskan bahwa admin dapat menginput data aset yang ada pada Fakultas Teknik Universitas Muhammadiyah Bengkulu dan sistem dapat memberikan informasi hasil klasifikasi data yang telah di input oleh admin tersebut serta sistem dapat juga langsung memberikan laporan data aset yang ada kepada pimpinan Fakultas.

\section{Data Flow Diagram (DFD)}

Data Flow Diagram (DFD) adalah alat pembuatan model yang memungkinkan profesional sistem untuk menggambarkan sistem sebagai suatu jaringan proses fungsional yang dihubungkan satu sama lain dengan alur data, baik secara manual maupun komputerisasi.

\section{Entity Relationship Diagram (ERD)}

ERD (Entity Relationship Diagram) adalah suatu model untuk menjelaskan hubungan antar data dalam basis data berdasarkan objek-objek dasar data yang mempunyai hubungan antar relasi. ERD untuk memodelkan struktur data dan hubungan antar data, untuk menggambarkannya digunakan beberapa notasi dan simbol.

\section{Code}

Pengkodean yang mengimplementasikan hasil desain kedalam kode atau bahasa yang dimengerti oleh mesin komputer dengan menggunakan bahasa matlab. Pada tahap pengkodean system penulisan kode program merupakan tahap penerjemahan desain sistem yang telah dibuat ke dalam bentuk perintah-perintah yang dimengerti komputer dengan mempergunakan bahasa pemrograman.

\section{Test (Pengujian)}

\section{Blackbox Testing}

Metode pengujian yang dipakai adalah black box testing. Black box testing atau test fungsional adalah pengujian program yang dilakukan oleh pengembang (Programmer) dengan memberikan input tertentu dan melihat hasil yang didapatkan dari input tersebut. dengan kata lain, black box testing terfokus pada fungsionalitas sistem. dalam melaksanakan blackbox testing, kami menggunakan beberapa kriteria yang akan diujikan [13]. kriteria-kriteria tersebut antara lain sebagai berikut 
1. Kemampuan Interface sistem untuk menjalankan fungsinya.

2. Kemampuan sistem untuk menjalankan fungsi interface.

3. Kemampuan sistem untuk menangani input-input form yang berada di luar boundary sistem.

4. Kemampuan sistem untuk menangani masalah keamanan.

\section{Whitebox Testing}

Whitebox testing adalah pengujian yang didasarkan pada pengecekan terhadap detail perancangan, menggunakan struktur kontrol dari desain program secara procedural untuk membagi pengujian ke dalam beberapa kasus pengujian. Secara sekilas dapat diambil kesimpulan white box testing merupakan petunjuk untuk mendapatkan program yang benar secara $100 \%$.

Pengujian white box untuk mengetahui cara kerja suatu perangkat lunak secara internal. Untuk menjamin operasi-operasi internal sesuai dengan spesifikasi yang telah ditetapkan dengan menggunakan struktur kendali dari prosedur yang dirancang. Kelebihan White Box Testing antara lain kesalahan Logika, ketidaksesuaian asumsi dan kesalahan pengetikan. Kelemahan White Box Testing adalah pada perangkat lunak yang jenisnya besar, metode white box testing ini dianggap boros karena melibatkan banyak sumberdaya untuk melakukannya [14]

\section{HASIL DAN ANALISIS}

Penelitian ini menghasilkan sebuah aplikasi Implementasi Algoritma Naïve Bayes Pada Pengelompokan Aset Fakultas Teknik Universitas Muhammadiyah Bengkulu. Dimana langkahlangkah proses tersebut akan dijabarkan sebagai berikut:

\section{Identifikasi Masalah}

Pada penelitian ini proses pertama yang dilakukan adalah mengidentifikasi masalah yang ada yaitu bagaimana menerapkan Naïve Bayes untuk pengelompokan aset Fakultas Teknik Universitas Muhammadiyah Bengkulu. Dimana Naive Bayes merupakan algoritma klasifikasi yang sederhana dimana setiap atribut bersifat independent dan memungkinkan berkontribusi terhadap keputusan akhir.

\section{Data}

Setelah didapat identifikasi masalah yang ada dalam menerapkan menerapkan algoritma Naïve Bayes untuk pengelompokan data aset, tahapan selanjutnya adalah pengumpulan dan pengolahan data. Data yang dimaksud merupakan data aset Fakultas Teknik Universitas Muhammadiyah Bengkulu seperti mouse, keyboard, printer, monitor dan infokus yang didapat pada saat melakukan penelitian

\section{Implemetasi}

\section{Membuat Database Sistem}

Dalam tahapan ini merupakan tahapan awal dalam menggunakan bahasa pemprograman PhpMysql. Dalam tahapan ini dibuat database yang akan berhubungan dengan system yaitu tabel mahasiswa dan tabel user.

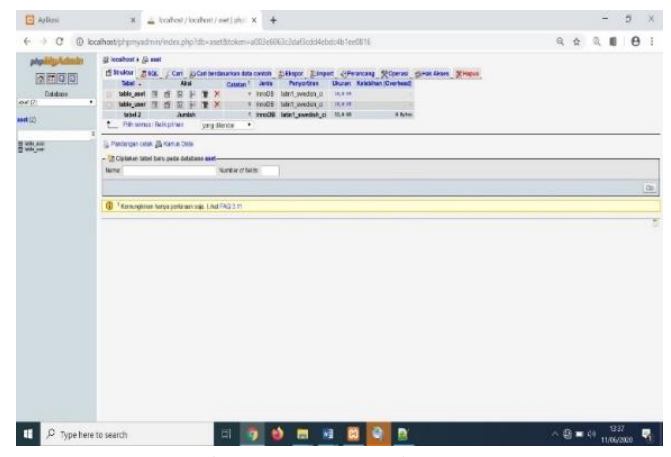

Gambar 4.1 Database aset. 
JSAI : Journal Scientific and Applied Informatics

Vol. 3, No. 3, November 2020, hal. 183 190

E-ISSN: 2614-3054; P-ISSN: 2614-3062, accredited by Kemenristekdikti, Sinta 5

DOI: 10.36085

\section{Login}

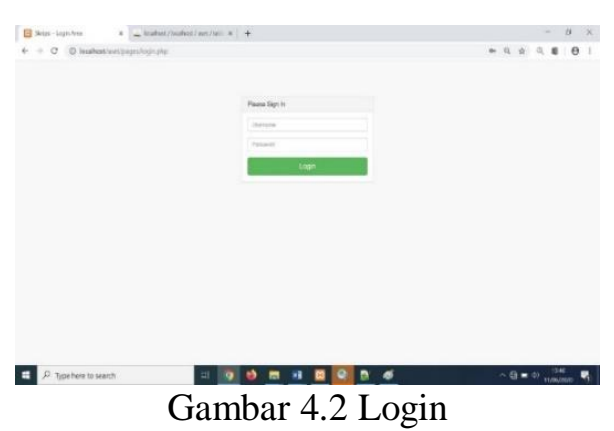

Halaman login pada system Implementasi Algoritma Naïve Bayes hanya bisa diakses oleh admin saja. Setelah admin berhasil login maka tugas admin selanjutnya adalah menginput data asset tampilan nya seperti gambar berikut:

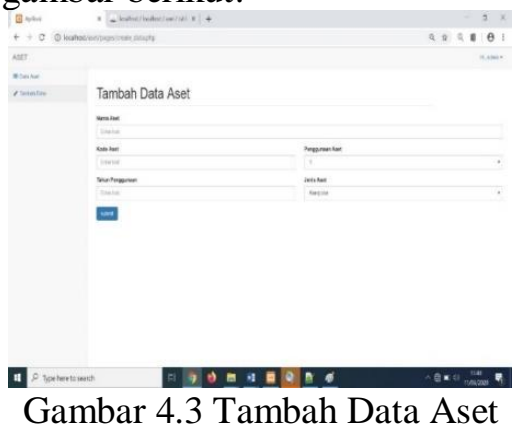

\section{Menu Utama}

Gambar 4.3 Tambah Data Aset

Setelah admin menginput data asset maka dalam menu utama akan tampak data asset yang telah diinput oleh admin.

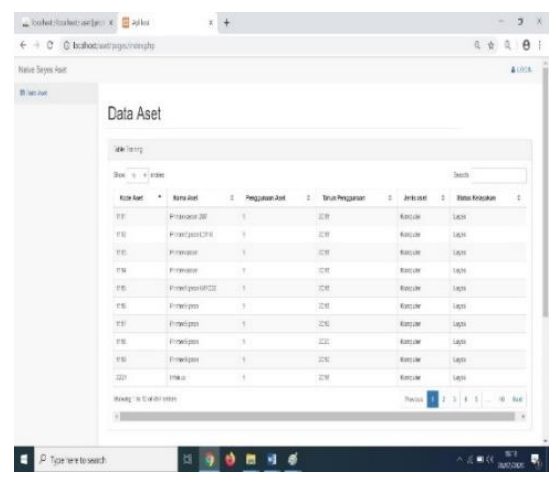

Gambar 4.4 Tabel Data Aset

Testing

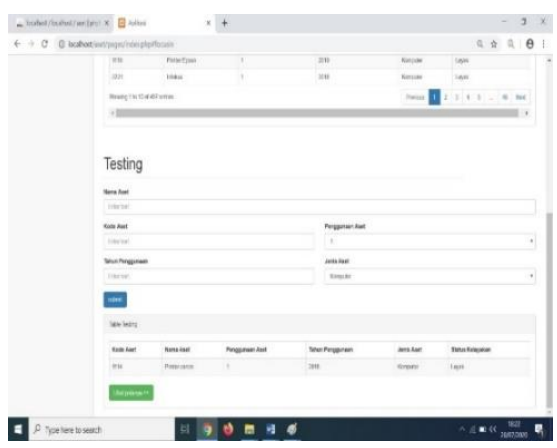

Gambar 4.5 Testing 
Tahapan testing ini merupakan tahapan test untuk menguji data aset dengan mengimplementasikan algoritma naïve bayes untuk pengelompokan data aset.

\section{PEMBAHASAN}

Dari hasil penelitian Implementasi Algoritma Naïve Bayes untuk pengelompokan data asset Fakultas Teknik Universitas Muhammadiyah Bengkulu. Dijelaskan bahwa Klasifikasi dengan Nä̈ve Bayes bekerja berdasarkan teori probabilitas yang memandang semua fitur dari data sebagai bukti dalam probabilitas.

Naive Bayes merupakan algoritma klasifikasi yang sederhana dimana setiap atribut bersifat independent dan memungkinkan berkontribusi terhadap keputusan akhir.

Contoh pengujian algoritma naïve bayes pada aplikasi dengan contoh data aset printer:

\section{Tahap 1 menghitung jumlah class/label}

$\mathrm{P}(\mathrm{Y}=$ Layak $)=457 / 457$ "Jumlah data "Layak" pada kolom 'Status Kelayakan' dibagi jumlah data"

$\mathrm{P}(\mathrm{Y}=$ Tidak Layak $)=$ 48/457 "Jumlah data "Tidak Layak" pada kolom 'Status Kelayakan' dibagi jumlah data"

\section{Tahap 2 menghitung jumlah kasus yang sama dengan class yang sama}

$\mathrm{P}($ Penggunaan Aset $=1 \mid \mathrm{Y}=$ Layak $)=409 / 457$ "jumlah data Penggunaan Aset "1 " dengan keterangan "Layak" dibagi jumlah data Layak" $\mathrm{P}($ Pengunaan Aset $=1 \mid \mathrm{Y}=$ Tidak Layak) = 0/48 "jumlah data Penggunaan Aset "1" dengan keterangan "Tidak Layak" dibagi jumlah data Tidak Layak"

$\mathrm{P}($ Tahun Penggunaan $=2018$ | $\mathrm{Y}=$ Layak 195/457 "jumlah data tahun penggunaan "2018" dengan keterangan "Layak" dibagi jumlah data Layak"

$\mathrm{P}($ Tahun Penggunaan $=2018 \mid \mathrm{Y}=$ Tidak Layak 0/48 "jumlah data tahun penggunaan "2018" dengan keterangan "Tidak Layak" dibagi jumlah data Tidak Layak"

$\mathrm{P}($ Jenis Aset $=$ Komputer $\mid \mathrm{Y}=$ Layak 457/457 "jumlah data jenis aset "Komputer" dengan keterangan "Layak" dibagi jumlah data Layak"

$\mathrm{P}($ Jenis Aset $=$ Komputer | Y = Tidak Layak 48/48 "jumlah data Jenis Aset "Komputer" dengan keterangan "Tidak Layak" dibagi jumlah data Tidak Layak"

\section{Tahap 3 kalikan semua hasil variable Layak \& Tidak Layak}

$\mathrm{P}($ Penggunaan Aset $=1)$. (Tahun Penggunaan $=2018)$. (Jenis Aset $=$ Komputer $) \mid$ Layak $)$ $=\{P(P($ penggunaan aset $=1 \mid Y=$ Layak $) . P($ tahun_penggunaan $=2018 \mid Y=$ Layak $)$.

$P($ Jenis Aset $=$ Komputer $\mid Y=$ Layak $)$

$=409 / 457.195 / 457.457 / 457.457 / 457$

$=0.38187877365944$

P $($ Pengunaan Aset $=1)$. (Tahun Penggunaan $=2018) .($ Jenis aset $=$ Komputer $) \mid$ Tidak Layak)

$=\{P(P($ Penggunaan Aset $=1 \mid Y=$ Tidak Layak $) . P($ Tahun Penggunaan $=2018 \mid Y=$ Tidak

Layak).$P($ Jenis Aset $=$ Komputer $\mid Y=$ Tidak Layak $)$

$=0 / 48 \cdot 0 / 48 \cdot 48 / 48 \cdot 48 / 457$

$=0$

Tahap 4 Bandingkan hasil class Layak \& Tidak Layak

Karena hasil (P|Layak) lebih besar dari (P|Tidak Layak) maka keputusanya adalah "LAYAK"Tahap 4 Bandingkan hasil class TEPAT \& TERLAMBAT

Karena hasil (P|Layak) lebih besar dari (P|Tidak Layak) maka keputusanya adalah "LAYAK". 


\section{Pengujian}

\section{Pengujian Blackbox Testing}

Blackbox testing merupakan metode pengujian perangkat lunak yang menguji fungsionalitas atau nonfungsionalitas sistem tanpa mengetahui struktur internal modul atau program yang akan diuji.

\section{Pengujian dengan White Box Testing}

Pada pengujian whitebox testing ini merupakan pengujian untuk melakukan pengecekan program yang akan dirunder. Listing programnya adalah login, logout, dan tambah data.

\section{KESIMPULAN (11 PT)}

Kesimpulan dari penelitian ini adalah:

1. Naïve bayes dapat menentukan status kelayakan data aset yang ada pada sistem dengan melihat pola dari naïve bayes itu sendiri didalam sistem.

2. Dengan adanya sistem ini dapat mempermudah Fakultas Teknik Universitas Muhammadiyah Bengkulu dalam menyimpan data aset yang ada.

\section{REFERENSI}

[1] Budi Harijanto. "Penerapan Algoritma Naïve Bayes untuk Klasifikasi Retensi Arsip". Jurnal Informatika Polinema. ISSN: 2407-070X. Volume 4, Edisi 2, Februari, 2018.

[2] Zhang, Harry. "The Optimality of Naive Bayes". FLAIRS conference. 2004.

[3] Walpole, E. R., Myers, R. H, "Ilmu Peluang dan Statistika untuk Insinyur dan Ilmuan, Edisi ke-4". Bandung, ITB. 1995.

[4] Antoni Wibowo. "MasteOf Information Technology". mti.binus.ac.id. klasifikasi. 2017

[5] Patil, T. R., Sherekar, M. S. "Performance Analysis of Naive Bayes and J48 Classification Algorithm for Data Classification", International Journal of Computer Science and Applications, Vol. 6, No. 2, Hal 256261, 2013.

[6] Bustami. "Penerapan algoritma naïve bayes Untuk mengklasifikasi data nasabah asuransi". JURNAL INFORMATIKA. Vol. 8, No. 1, Januari 2014.

[7] Gusmelia Testiana. "Perancangan Model Prediksi Kelulusan Mahasiswa Tepat Waktu pada UIN Raden Fatah". JUSIFO (Jurnal Sistem Informasi) - Vol. 02, No.1, Juni, 2018.

[8] Nagendra, V, K and Rajendra, C. "Customer Behaviour Analysis Using Cba ( Data Mining Approach )," National Conference on Research Trends in Computer Science and Technology, Vol. 3, No. 1, pp. 65-68, 2012

[9] Erfan Karyadi Putra. "Analisis Penerapan Algoritma Naive Bayes Untuk Klasifikasi prioritas pengembangan jalan di provinsi Kalimantan selatan. Technologia" Vol 9, No.2, April - Juni, 2018

[10] Nugroho. 'PHP dan MySQL dengan editor dreamweaver MX'. Yogyakarta : ANDI. 2004.

[11]Dio Lavarino. "Rancang Bangun E - Voting Berbasis Website Di Universitas Negeri Surabaya". Jurnal Manajemen Informatika. Volume 6 Nomor 1 Tahun 2016, 72-81, 2016

[12] Syarli. "Metode Naïve Bayes Untuk Prediksi Kelulusan (Studi Kasus: Data Mahasiswa Baru Perguruan Tinggi)". Jurnal Ilmiah Ilmu Komputer, Vol. 2, No. 1, April, 2016.

[13] Hasan Bisry Isa Alfaris. "Implementasi black box testing pada sistem informasi Pendaftaran santri berbasis web dengan menggunakan Php dan mysql". Jurnal SAINTEKBU: Jurnl Sains dan Teknologi. Volume 6 no. 1 Februari, 2013.

[14]Nidhra, Srinivas, and Dondeti, Jagruthi. "Blackbox and Whitebox Testing Techniques - A Literature Review". International Journal of Embedded Systems and Applications (IJESA) Vol.2, No.2, June, 2012 